\title{
Estimating virtual nitrogen inputs to integrated U.S. corn ethanol and animal food systems
}

\section{Supporting information}

\author{
Mikaela Algren, ${ }^{1 *}$ Amy E. Landis, ${ }^{1}$ and Chris Costello ${ }^{2}$ \\ ${ }^{1}$ Colorado School of Mines, Golden, CO 80401, USA \\ ${ }^{2}$ Pennsylvania State University, University Park, PA 16802, USA
}

Number of pages: 15

Number of tables: 8

Number of figures: 3 


\section{CONTENTS}

Table S1: Production quantities for crops tracked in CSNANI, ethanol feed coproducts, and ethanol

Table S2: Crop and ethanol feed coproduct exports

Table S3: Crop and ethanol feed coproduct harvested areas

Table S4: Populations for the livestock types tracked in CSNANI

Table S5: $\mathrm{N}$ fertilization rates used in CSNANI

Table S6: Percent of available crop allocated to animals in CSNANI

Table S7: Comparison of ethanol feed coproduct diet dry mass proportions in CSNANI and limits established in literature for each animal group

Table S8: Allocation factors for coproducts of dry and wet milling

Figure S1: Fertilizer N inputs per liter of ethanol fuel from 1997-2012 for different allocation methods

Figure S2: Fertilizer and fixation N inputs to beef feeds per kg beef protein from 1997-2012 for different allocation methods

Figure S3: Fertilizer and fixation N inputs to dairy feeds per kg milk protein from 1997-2012 for different allocation methods 
Tables S1-S5 contain data for all year-dependent inputs used in CSNANI, with the exceptions of human population and atmospheric $\mathrm{N}$ deposition since the corresponding model functions were not used in this study.

Table S1. Production quantities for crops tracked in CSNANI, ethanol feed coproducts, and ethanol. These are the non-animal commodities tracked in CSNANI. Production data for crops comes from the USDA Agricultural Census, ${ }^{[1]}$ DGS, CGF, and CGM quantities are calculated using data from USDA ERS feed grains yearbook tables, ${ }^{[2]}$ and ethanol production data comes from the USDA ERS fuel ethanol supply and disappearance table. ${ }^{[3]}$ Values for crops and ethanol coproducts are in million metric tons. Ethanol values are in billion liters.

\begin{tabular}{|c|c|c|c|c|}
\hline & 1997 & 2002 & 2007 & 2012 \\
\hline \multicolumn{5}{|c|}{ million metric tons } \\
\hline Corn grain (total) & 218 & 219 & 323 & 262 \\
\hline Corn grain (corn for ethanol removed) & 207 & 198 & 255 & 160 \\
\hline Corn silage & 80.2 & 88.1 & 94.6 & 103 \\
\hline Wheat & 57.5 & 41.1 & 52.0 & 57.0 \\
\hline Oats & 2.20 & 1.59 & 1.30 & 0.95 \\
\hline Barley & 7.32 & 4.67 & 4.51 & 4.68 \\
\hline Sorghum grain & 14.2 & 8.47 & 12.3 & 6.71 \\
\hline Sorghum silage & 4.21 & 3.54 & 5.23 & 5.12 \\
\hline Potatoes & 20.9 & 20.5 & 20.2 & 21.1 \\
\hline Rye & 0.17 & 0.18 & 0.17 & 0.17 \\
\hline Alfalfa hay & 59.8 & 62.2 & 59.3 & 44.9 \\
\hline Other hay & 66.7 & 75.7 & 78.1 & 65.8 \\
\hline Soybeans & 68.2 & 73.7 & 70.3 & 79.7 \\
\hline Cropland pasture & 58.4 & 54.9 & 32.4 & 11.6 \\
\hline Noncropland pasture & 193 & 193 & 198 & 200 \\
\hline Rice & 8.27 & 9.54 & 9.01 & 9.08 \\
\hline Peanuts & 1.53 & 1.42 & 1.68 & 3.02 \\
\hline Corn gluten feed (CGF) & 1.27 & 1.72 & 1.34 & 0.35 \\
\hline Corn gluten meal (CGM) & 0.23 & 0.31 & 0.24 & 0.06 \\
\hline \multirow[t]{2}{*}{ Distillers grains and solubles (DGS) } & 1.34 & 3.57 & 17.5 & 28.2 \\
\hline & \multicolumn{4}{|c|}{ billion liters } \\
\hline Ethanol & 5.55 & 8.10 & 24.7 & 50.0 \\
\hline
\end{tabular}


Table S2. Crop and ethanol feed coproduct exports. Exports are used with production data to determine domestic availability of these products for allocation to humans and animals in CSNANI. Export quantities for CGF and CGM were assumed to be negligible.

\begin{tabular}{|c|c|c|c|c|}
\hline & 1997 & 2002 & 2007 & 2012 \\
\hline & \multicolumn{4}{|c|}{ million metric tons } \\
\hline Corn grain & 38.2 & 40.3 & 61.9 & 18.5 \\
\hline Corn silage & 1.6 & 4.1 & 4.1 & 4.3 \\
\hline Wheat & 28.3 & 23.1 & 34.4 & 27.5 \\
\hline Oats & 0.1 & 0.1 & 0.1 & 0.1 \\
\hline Barley & 1.8 & 0.8 & 1.6 & 0.7 \\
\hline Sorghum grain & 5.1 & 5.4 & 5.6 & 1.7 \\
\hline Sorghum silage & 0.3 & 0.0 & 1.4 & 0.2 \\
\hline Potatoes & 1.8 & 1.9 & 2.5 & 3.1 \\
\hline Rye & 0.0 & 0.0 & 0.0 & 0.0 \\
\hline Alfalfa hay & 1.0 & 1.1 & 0.9 & 1.0 \\
\hline Other hay & 1.6 & 1.6 & 1.5 & 1.6 \\
\hline Soybeans & 23.8 & 28.4 & 31.5 & 36.1 \\
\hline Cropland pasture & 0.0 & 0.0 & 0.0 & 0.0 \\
\hline Noncropland pasture & 0.0 & 0.0 & 0.0 & 0.0 \\
\hline Rice & 3.2 & 4.6 & 3.9 & 3.9 \\
\hline Peanuts & 0.3 & 0.2 & 0.3 & 0.5 \\
\hline Corn gluten feed (CGF) & 0.0 & 0.0 & 0.0 & 0.0 \\
\hline Corn gluten meal (CGM) & 0.0 & 0.0 & 0.0 & 0.0 \\
\hline Distiller's grains and solubles (DGS) & 0.6 & 0.8 & 3.9 & 8.2 \\
\hline
\end{tabular}


Table S3. Crop and ethanol feed coproduct harvested areas. Harvested areas (and virtual harvested areas in the cases of ethanol and coproducts) are used with $\mathrm{N}$ fertilization rates to calculate crop fertilizer $\mathrm{N}$ inputs.

\begin{tabular}{|c|c|c|c|c|}
\hline & 1997 & 2002 & 2007 & 2012 \\
\hline & \multicolumn{4}{|c|}{ thousand $\mathbf{k m}^{2}$} \\
\hline Corn grain (total) & 282.68 & 276.32 & 349.29 & 354.00 \\
\hline Corn grain (corn for ethanol removed) & 268.79 & 250.09 & 274.91 & 215.83 \\
\hline Corn silage & 23.15 & 27.02 & 24.17 & 29.09 \\
\hline Wheat & 238.13 & 184.23 & 206.14 & 198.46 \\
\hline Oats & 10.83 & 8.07 & 6.10 & 4.36 \\
\hline Barley & 24.03 & 16.23 & 14.23 & 13.26 \\
\hline Sorghum grain & 34.20 & 27.28 & 27.32 & 20.73 \\
\hline Sorghum silage & 1.55 & 1.64 & 1.82 & 1.89 \\
\hline Potatoes & 5.47 & 5.11 & 4.57 & 4.72 \\
\hline Rye & 1.09 & 1.15 & 1.08 & 1.07 \\
\hline Alfalfa hay & 86.21 & 91.59 & 81.91 & 67.27 \\
\hline Other hay & 159.65 & 175.22 & 175.43 & 163.49 \\
\hline Soybeans & 267.64 & 292.97 & 258.64 & 307.96 \\
\hline Cropland pasture & 260.62 & 244.75 & 144.53 & 51.70 \\
\hline Noncropland pasture & 1719.49 & 1718.50 & 1763.95 & 1787.64 \\
\hline Rice & 12.59 & 12.90 & 11.14 & 10.88 \\
\hline Peanuts & 5.47 & 4.95 & 4.86 & 6.56 \\
\hline Corn gluten feed (CGF) & 1.64 & 2.17 & 1.44 & 0.47 \\
\hline Corn gluten meal (CGM) & 0.30 & 0.39 & 0.26 & 0.09 \\
\hline Distiller's grains and solubles (DGS) & 1.73 & 4.51 & 18.91 & 38.02 \\
\hline Ethanol fuel & 9.98 & 18.92 & 53.53 & 99.41 \\
\hline
\end{tabular}


Table S4. Populations for the livestock types tracked in CSNANI. Data comes from the USDA Agricultural Census. ${ }^{[1]}$

\begin{tabular}{|c|c|c|c|c|}
\hline & 1997 & 2002 & 2007 & 2012 \\
\hline & \multicolumn{4}{|c|}{ million animals } \\
\hline \multicolumn{5}{|l|}{ beef } \\
\hline fattened cattle & 10.9 & 11.3 & 11.0 & 10.2 \\
\hline beef breeding herd & 35.7 & 35.0 & 34.4 & 30.3 \\
\hline beef calves & 11.5 & 11.4 & 11.2 & 9.97 \\
\hline beef heifers & 2.09 & 2.03 & 1.99 & 1.76 \\
\hline beef stockers & 26.8 & 26.3 & 27.0 & 25.5 \\
\hline \multicolumn{5}{|l|}{ dairy } \\
\hline milk cows & 9.09 & 9.10 & 9.26 & 9.25 \\
\hline dairy calves & 2.43 & 2.43 & 2.47 & 2.47 \\
\hline dairy heifers & 0.75 & 0.75 & 0.76 & 0.76 \\
\hline dairy stockers & 0.00 & 0.00 & 0.00 & 0.00 \\
\hline \multicolumn{5}{|l|}{ pork } \\
\hline hogs for breeding & 6.83 & 6.17 & 6.29 & 5.71 \\
\hline hogs for slaughter & 54.1 & 61.8 & 69.5 & 67.5 \\
\hline \multicolumn{5}{|l|}{ chicken } \\
\hline layers & 313 & 334 & 349 & 350 \\
\hline chicken pullets & 80.7 & 85.3 & 86.9 & 92.7 \\
\hline chicken broilers & 1120 & 1410 & 1510 & 1430 \\
\hline \multicolumn{5}{|l|}{ turkeys } \\
\hline breeding turkeys & 5.50 & 4.65 & 5.36 & 5.04 \\
\hline slaughter turkeys & 125 & 113 & 123 & 117 \\
\hline sheep & 7.80 & 6.32 & 5.80 & 5.34 \\
\hline horses & 2.42 & 3.64 & 4.02 & 3.61 \\
\hline goats & 0.96 & 0.59 & 0.54 & 0.57 \\
\hline
\end{tabular}


In the NANI Toolbox, N fertilizer inputs are estimated using county-level USGS fertilizer sales estimates. ${ }^{[4]}$ For the original CSNANI, county-level harvested areas (nationwide totals shown in Table S3) and crop-specific $\mathrm{N}$ fertilization rates were used (Table S5). For potatoes and rice, the average fertilization rate was calculated over multiple data years. ${ }^{[5,6]}$ In order to more accurately estimate changes in fertilization $\mathrm{N}$ inputs over time, CSNANI now uses yearly, area-weighted, national-average $\mathrm{N}$ fertilization rates for corn, wheat, and soybeans in each year. This data was extracted from US Fertilizer Use and Price Tables from the USDA ERS. ${ }^{[7]}$

Table S5. $\mathbf{N}$ fertilization rates used in CSNANI. Area-weighted, national-average N fertilization rates come from U.S. Fertilizer Use and Price Tables from the USDA ERS ${ }^{[7]}$ for yearly corn grain, wheat, and soybean data. National averages fertilization rates are from the Agricultural Chemical Usage Surveys ${ }^{[5]}$ for oats, barley, sorghum, potatoes, rice, and peanuts. For rye and hays, the fertilization rate is a conservative estimate based on UMN Extension recommendations. ${ }^{[8]}$ Fertilization rates for corn grain and silage are assumed to be the same, and fertilization rates for sorghum grain and silage are assumed to be the same.

\begin{tabular}{|c|c|c|c|c|}
\hline & 1997 & 2002 & 2007 & 2012 \\
\hline \multicolumn{5}{|c|}{ metric tons $\mathrm{N} / \mathrm{km}^{2}$} \\
\hline Corn (grain and silage) ${ }^{[7]}$ & 14.4 & 14.7 & 15.0 & 15.3 \\
\hline Wheat ${ }^{[7]}$ & 6.52 & 6.55 & 6.16 & 6.80 \\
\hline \multirow[t]{2}{*}{ Soybeans ${ }^{[7]}$} & 0.56 & 0.47 & 0.47 & 0.48 \\
\hline & & rate & \multicolumn{2}{|c|}{ data years averaged } \\
\hline Oats ${ }^{[5]}$ & & 6.03 & & 2005 \\
\hline Barley ${ }^{[5]}$ & & 6.73 & & 2003 \\
\hline Sorghum (grain and silage) & & 9.09 & & 2003 \\
\hline Potatoes & & 23.6 & & 2001 \\
\hline $\boldsymbol{R y e}^{[8]}$ & & 4.40 & & NA \\
\hline Alfalfa hay ${ }^{[8]}$ & & 2.20 & & NA \\
\hline Other hay ${ }^{[8]}$ & & 2.20 & & NA \\
\hline Rice $^{[5]}$ & & 17.9 & & 2006 \\
\hline Peanuts ${ }^{[5]}$ & & 1.39 & & 2004 \\
\hline
\end{tabular}


Although silages are classified as forage in the Statistics Canada dataset, silages are considered grain instead of forage when the Canadian data are used to calculated forage to grain $\mathrm{N}$ ratios. The forage to grain ratios that result when silage is classified as forage cause the animal diet model to "demand" more forage $\mathrm{N}$ than we estimate is produced in the US. This is likely because of differences in silage utilization between Canada and the US. Considering the uncertainty associated with applying Canadian feed data to the U.S. agricultural system, we prioritized keeping allocations of crops to animals within the physical quantities of crop produced over adhering to the exact forage and grain classifications used in the Canadian study. We do not believe this has an adverse effect on results. In ensuring that the quantities of crops in modeled animal diets do not exceed quantities of crops available for animals in the U.S., we reduce the risk of overestimating virtual $\mathrm{N}$ impacts associated with animal diets. The total mass of each forage crop allocated to animals in the model is $70-81 \%$ of the quantity produced for animals in the U.S., and the total mass of each grain crop allocated to animals is $89-101 \%$ of the total produced for animals in the U.S. in model years 1997 to 2012 (Table S6).

Table S6. Percent of available crop allocated to animals in CSNANI. In this case, "available crop" refers to crop available for domestic animal consumption. The grayed rows are the crops or feeds considered a grain in CSNANI. The white rows are forage crops. CGF, CGM, and DGS are corn gluten feed, corn gluten meal, and distillers grains and solubles, respectively.

\begin{tabular}{l|cccc}
\hline \multicolumn{1}{l|}{} & $\mathbf{1 9 9 7}$ & $\mathbf{2 0 0 2}$ & $\mathbf{2 0 0 7}$ & $\mathbf{2 0 1 2}$ \\
\hline Corn - grain & $89 \%$ & $100 \%$ & $95 \%$ & $89 \%$ \\
Corn - silage & $89 \%$ & $100 \%$ & $95 \%$ & $89 \%$ \\
Wheat & $89 \%$ & $100 \%$ & $95 \%$ & $89 \%$ \\
Oats & $89 \%$ & $100 \%$ & $95 \%$ & $89 \%$ \\
Barley & $89 \%$ & $100 \%$ & $95 \%$ & $89 \%$ \\
Sorghum - grain & $89 \%$ & $101 \%$ & $95 \%$ & $90 \%$ \\
Sorghum- silage & $89 \%$ & $100 \%$ & $95 \%$ & $89 \%$ \\
Rye & $89 \%$ & $100 \%$ & $95 \%$ & $89 \%$ \\
Alfalfa hay & $72 \%$ & $70 \%$ & $74 \%$ & $79 \%$ \\
Other hay & $72 \%$ & $70 \%$ & $74 \%$ & $80 \%$ \\
Soybeans & $89 \%$ & $100 \%$ & $95 \%$ & $89 \%$ \\
Cropland pasture & $72 \%$ & $70 \%$ & $74 \%$ & $81 \%$ \\
Noncropland pasture & $72 \%$ & $70 \%$ & $74 \%$ & $81 \%$ \\
CGF & $95 \%$ & $95 \%$ & $95 \%$ & $95 \%$ \\
CGM & $95 \%$ & $95 \%$ & $95 \%$ & $95 \%$ \\
DGS & $95 \%$ & $95 \%$ & $95 \%$ & $95 \%$
\end{tabular}


Literature was used to determine limits on ethanol coproduct consumption for comparison with modeled coproduct consumption in CSNANI (Table S7). The dry mass proportion of ethanol feed coproducts within modeled animal diets in CSNANI never exceeded animal-specific optimal or allowable consumption levels specified in the evaluated literature. ${ }^{[9,10,11,12]}$

Table S7. Comparison of ethanol feed coproduct diet dry mass proportions in CSNANI and limits established in literature for each animal group.

\begin{tabular}{|c|c|c|c|c|c|}
\hline & 1997 & 2002 & 2007 & 2012 & Limit in literature \\
\hline & \multicolumn{5}{|c|}{ coproduct \% of total diet dry mass } \\
\hline \multicolumn{6}{|c|}{ re } \\
\hline fattened cattle & $3 \%$ & $6 \%$ & $23 \%$ & $37 \%$ & $40 \%{ }^{[12]}$ \\
\hline beef breeding herd & $0 \%$ & $0 \%$ & $1 \%$ & $2 \%$ & -- \\
\hline beef calves & $0 \%$ & $0 \%$ & $0 \%$ & $0 \%$ & -- \\
\hline beef heifers & $1 \%$ & $2 \%$ & $5 \%$ & $6 \%$ & -- \\
\hline beef stockers & $0 \%$ & $1 \%$ & $2 \%$ & $3 \%$ & -- \\
\hline \multicolumn{6}{|l|}{ dairy } \\
\hline milk cows & $1 \%$ & $2 \%$ & $7 \%$ & $10 \%$ & $20 \%{ }^{[10]}$ \\
\hline dairy calves & $0 \%$ & $0 \%$ & $0 \%$ & $0 \%$ & -- \\
\hline dairy heifers & $2 \%$ & $5 \%$ & $16 \%$ & $15 \%$ & $20 \%[10]$ \\
\hline dairy stockers & $0 \%$ & $0 \%$ & $0 \%$ & $0 \%$ & -- \\
\hline \multicolumn{6}{|l|}{ pork } \\
\hline hogs for breeding & $1 \%$ & $3 \%$ & $9 \%$ & $14 \%$ & $30-50 \%^{[11,12]}$ \\
\hline hogs for slaughter & $0 \%$ & $1 \%$ & $2 \%$ & $3 \%$ & $30 \%[11,12]$ \\
\hline \multicolumn{6}{|l|}{ chicken } \\
\hline chicken layers & $0 \%$ & $1 \%$ & $3 \%$ & $4 \%$ & $10 \%[9,12]$ \\
\hline chicken pullets & $1 \%$ & $2 \%$ & $5 \%$ & $7 \%$ & $10 \%[9,12]$ \\
\hline chicken broilers & $0 \%$ & $1 \%$ & $2 \%$ & $3 \%$ & $10 \%[9,12]$ \\
\hline \multicolumn{6}{|l|}{ turkey } \\
\hline breeding turkeys & $0 \%$ & $0 \%$ & $0 \%$ & $0 \%$ & $10 \%[9,12]$ \\
\hline slaughter turkeys & $0 \%$ & $1 \%$ & $2 \%$ & $3 \%$ & $10 \%[9,12]$ \\
\hline sheep & $0 \%$ & $0 \%$ & $0 \%$ & $0 \%$ & -- \\
\hline horses & $0 \%$ & $0 \%$ & $0 \%$ & $0 \%$ & -- \\
\hline goats & $0 \%$ & $0 \%$ & $0 \%$ & $0 \%$ & -- \\
\hline
\end{tabular}


The results of environmental impact assessments can be highly sensitive to the method used to allocate impact between coproducts. Impact allocation factors for ethanol and coproducts of both wet milling and dry milling, based on output mass, energy content, and market value, were reported by Shapouri et al. (2002) ${ }^{[13]}$ and are included Table S8. The default allocation method used in the CSNANI model is a mass allocation method based on the starch content of corn (input mass in Table S8).

Table S8. Allocation factors for coproducts of dry and wet milling. Output mass, energy content, and market value factors come from Shapouri et al. (2002). ${ }^{[13]}$ The allocation factor used in this study was based on the starch content of corn (i.e., input mass).

\begin{tabular}{c|cc}
\hline & Ethanol & Feed coproducts \\
\hline Output mass: & 0.51 & \\
Dry milling & 0.52 & 0.49 \\
Wet milling & & 0.48 \\
Energy content: & 0.57 & 0.43 \\
Dry milling & 0.61 & 0.39 \\
Wet milling & & \\
Market value: & 0.76 & 0.24 \\
Dry milling & 0.70 & 0.30 \\
Wet milling & & \\
Input mass: & 0.72 & 0.28 \\
Dry milling & 0.74 & 0.26 \\
Wet milling &
\end{tabular}


The market value allocation results (Figure S1c) are almost identical to the results for mass allocation based on corn starch content presented in the main paper (Figure 2).

a) output mass
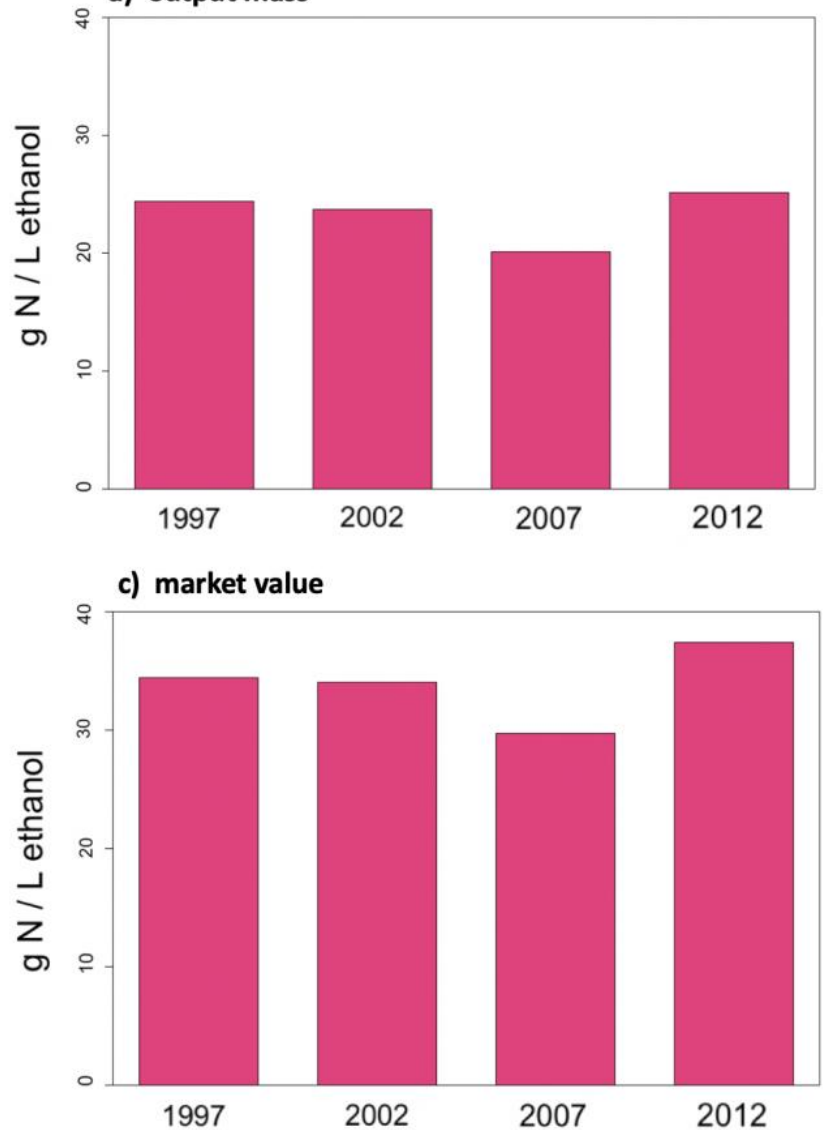

b) energy content

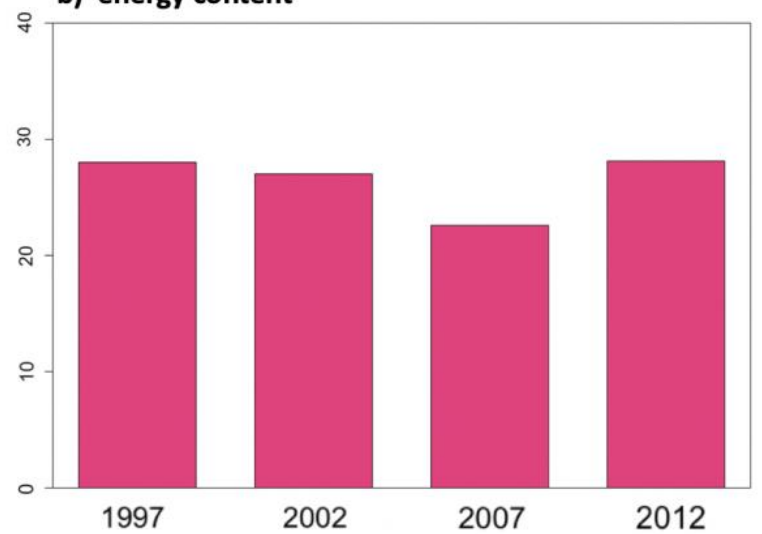

d) full allocation to ethanol fuel

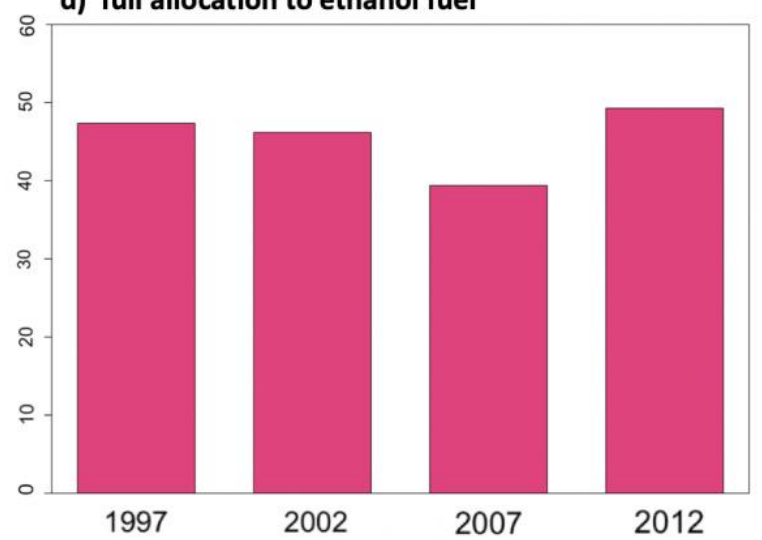

Figure S1: Fertilizer $N$ inputs to soil per liter of ethanol fuel from 1997-2012 for different allocation methods. Each scenario (a-d) uses a different allocation method. In scenario a, virtual $\mathrm{N}$ inputs of the ethanol production system are allocated based on output masses, in $\mathbf{b}$ allocations are based on energy content, and in $\mathbf{c}$ allocations are based on market value (Table S8). Scenario d shows estimates of ethanol fuel impacts where all virtual N inputs to the ethanol production system are allocated to fuel. Note that the scale for $\mathbf{d}$ differs from those for a-c, and runs from $0-60 \mathrm{~g} \mathrm{~N} / \mathrm{L}$. 
In the extreme scenario where all fertilizer $\mathrm{N}$ inputs to corn used in ethanol production are allocated to ethanol feed coproducts (Figure S2d), the modeled decrease in N inputs per kg beef protein from 1997-2012 is only 3\% (as compared to 19\% using the starch-content-based allocation method, Figure 4a in the main paper).
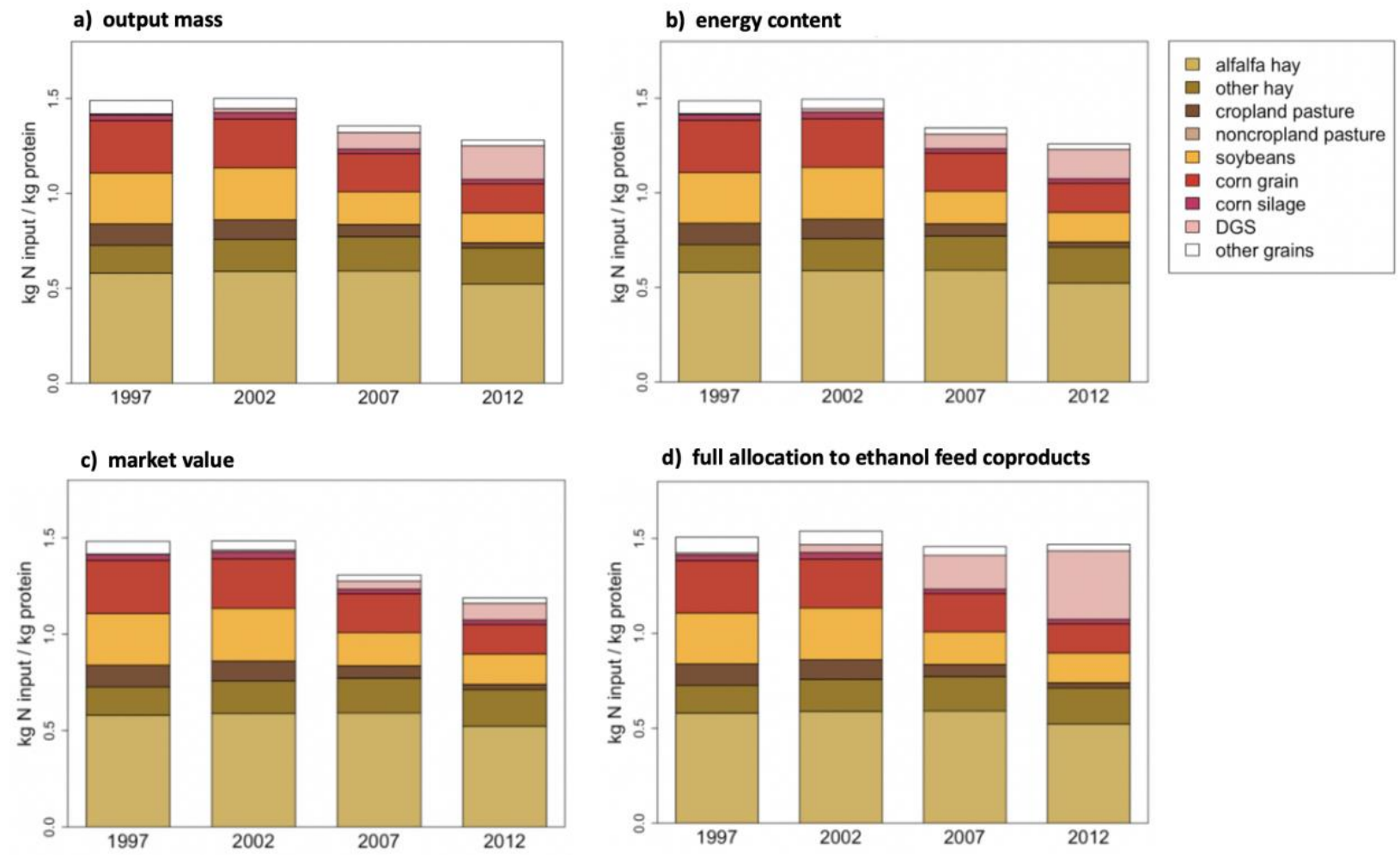

Figure S2. Fertilizer and fixation $N$ inputs to beef feeds per kg beef protein from 1997-2012 for different allocation methods. Each scenario (a-d) uses a different allocation method. In scenario a, virtual $\mathrm{N}$ inputs of the ethanol production system are allocated based on output masses, in $\mathbf{b}$ allocations are based on energy content, and in c allocations are based on market value (Table S8). The market-value-allocation results are almost identical to the input-mass-allocation results presented in the main paper. Scenario $\mathbf{d}$ shows estimates of beef $\mathrm{N}$ inputs where all virtual $\mathrm{N}$ inputs to the ethanol production system are allocated to ethanol feed coproducts. 
The change in $\mathrm{N}$ inputs per kg milk protein from 1997-2012 where all fertilizer $\mathrm{N}$ inputs to corn used in ethanol production are allocated to ethanol feed coproducts (Figure S3d) is an increase in 4\% (as compared to a decrease in $13 \%$ using the starch-based allocation method, Figure $\mathbf{4 c}$ in the main paper).
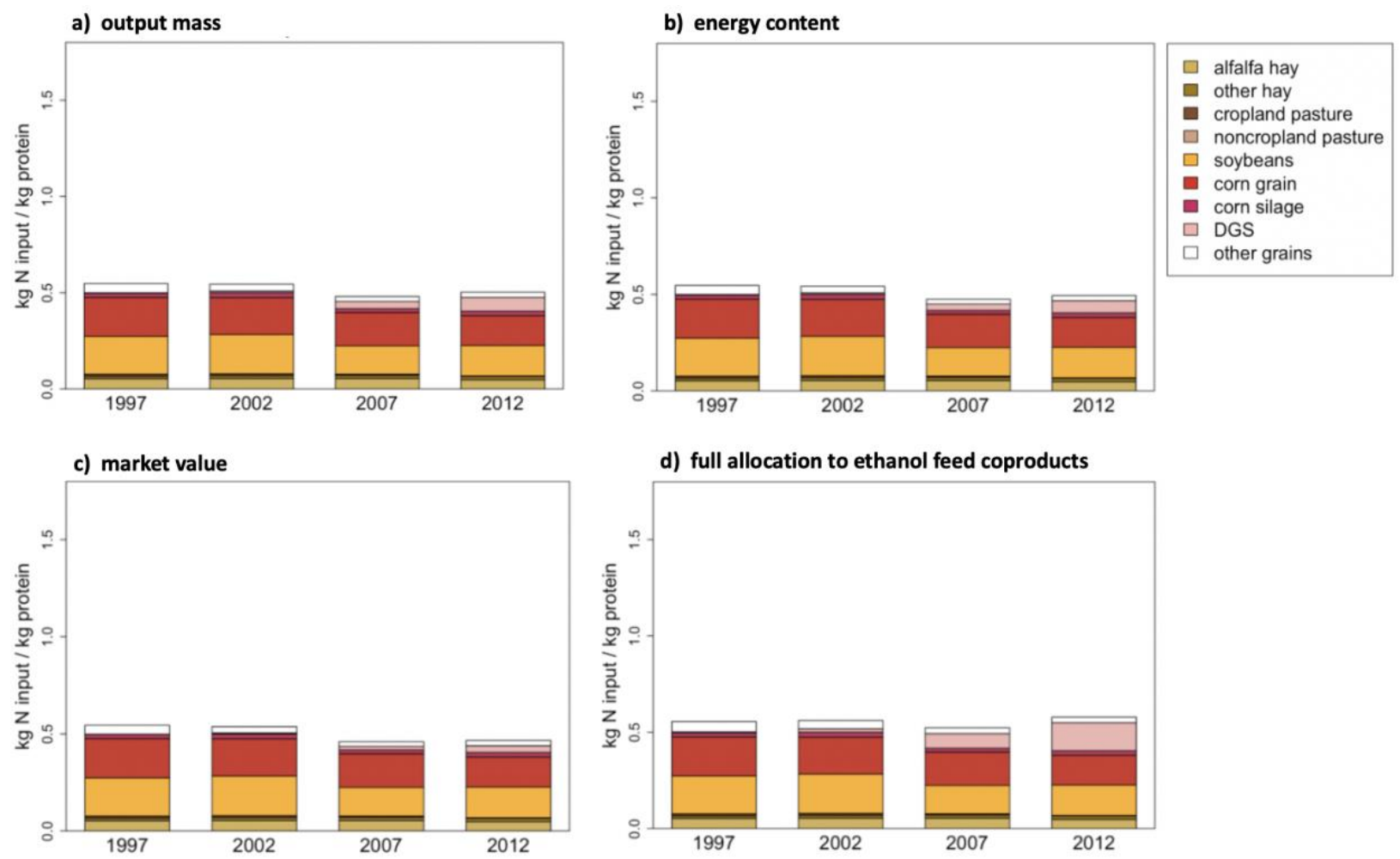

Figure S3. Fertilizer and fixation $N$ inputs to dairy feeds per kg dairy protein from 1997-2012 for different allocation methods. Each scenario (a-d) uses a different allocation method. In scenario a, virtual $\mathrm{N}$ inputs of the ethanol production system are allocated based on output masses, in $\mathbf{b}$ allocations are based on energy content, and in c allocations are based on market value (Table S8). The market-value-allocation results are almost identical to the input-mass-allocation results presented in the main paper. Scenario $\mathbf{d}$ shows estimates of beef $\mathrm{N}$ inputs where all virtual $\mathrm{N}$ inputs to the ethanol production system are allocated to ethanol feed coproducts. 
Although the efficiency of $\mathrm{N}$ use in ethanol production and in the feeding of cattle has improved on average, we do not see a reduction in total $\mathrm{N}$ inputs to the Mississippi River and Atchafalaya watersheds from 1997-2012 (Figure S4). This is because total corn production has increased, and production of other crops that would be replaced by ethanol coproducts in animal diets has not decreased enough to compensate for the $\mathrm{N}$ inputs associated with increased corn production.

\section{a) fertilizer $\mathbf{N}$}

\begin{tabular}{|l|l|}
\hline$\square$ & corn grain \\
$\square$ & corn silage \\
$\square$ & wheat \\
$\square$ & oats \\
$\square$ & barley \\
$\square$ & sorghum grain \\
$\square$ & sorghum silage \\
$\square$ & potatoes \\
$\square$ & rye \\
$\square$ alfalfa hay \\
$\square$ other hay \\
$\square$ soybeans \\
$\square$ cropland pasture \\
$\square$ noncropland pasture \\
$\square$ rice \\
$\square$ peanuts \\
$\square$ CGF \\
$\square$ CGM \\
$\square$ DGS \\
$\square$ ethanol \\
\hline
\end{tabular}
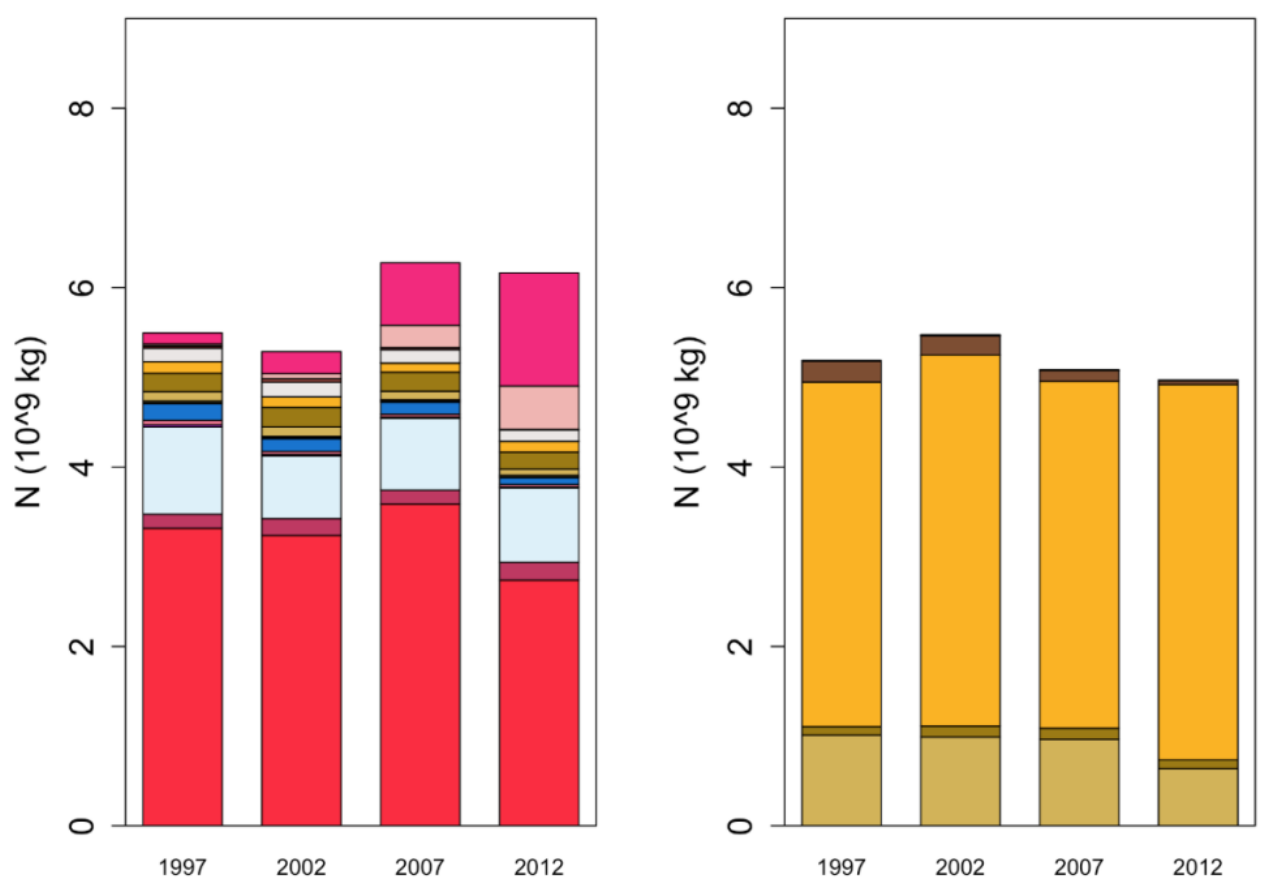

Figure S4. Total commodity-disaggregated fertilizer (a) and fixation (b) inputs for the Mississippi and Atchafalaya watersheds. 


\section{SOURCES}

1. USDA. (2012b). "Census of Agriculture." Retrieved June 2, 2014, from http://www.agcensus.usda.gov/Publications/2012/.

2. USDA. (2018a). "Feed Grains Data - All Years." 2018, from https://www.ers.usda.gov/webdocs/DataFiles/50048/Feed\%20Grains\%20Yearbook\%20TablesAll\%20Years.xls?v=43327.

3. USDA. (2018b). "Fuel ethanol supply and disappearance calendar year." Retrieved June 15, 2018, from https://www.ers.usda.gov/webdocs/DataFiles/53657/table02.xls?v=43164.

4. Brakebill, J. W. a. G., J.M. (2017). County-Level Estimates of Nitrogen and Phosphorus from Commercial Fertilizer for the Conterminous United States, 1987-2012: U.S. Geological Survey data release.

5. USDA. (2012a). "Agricultural Chemical Usage - Field Crops and Potatoes." from http://usda.mannlib.cornell.edu/MannUsda/viewDocumentInfo.do?documentID=1560.

6. Costello, C., X. Xue and R. W. Howarth (2015). "Comparison of production-phase environmental impact metrics derived at the farm-and national-scale for United States agricultural commodities." Environmental Research Letters 10(11): 114004.

7. USDA. (2018c). "U.S. Fertilizer Use and Price." Retrieved October 11, 2018, from http://www.ers.usda.gov/Data/FertilizerUse/.

8. UMN (2018). Crop-specific needs, Nutrient Management Extension.

9. Świątkiewicz, S. and J. Koreleski (2008). "The use of distillers dried grains with solubles (DDGS) in poultry nutrition." World's Poultry Science Journal 64(2): 257-266.

10. Schingoethe, D. J., K. F. Kalscheur, A. R. Hippen and A. D. Garcia (2009). "Invited review: The use of distillers products in dairy cattle diets." Journal of Dairy Science 92(12): 5802-5813.

11. Stein, H. and G. Shurson (2009). "Board-invited review: The use and application of distillers dried grains with solubles in swine diets." Journal of animal science 87(4): 1292-1303.

12. USGC (2012). A guide to distiller's dried grains with solubles, U.S. Grains Council.

13. Shapouri, H., J. A. Duffield and M. Wang (2002). The energy balance of corn ethanol: an update, EERE Publication and Product Library. 